\title{
Red tape frustrates Europe's fund-seekers
}

Ralf Jox, Munich

Scientists who burnt the midnight oil for months to apply for the first round of funding under the European Union's new Framework research programme are angry about the complex bureaucracy they were forced to endure.

Of more than 10,000 applications in the first round of the $€ 17.5$-billion (US\$19.5billion) Sixth Framework Programme (FP6), about a quarter have been recommended for funding, a European Commission official told Nature last week. This is higher than for some key areas in the equivalent stage of the Fifth Framework Programme (see Nature 404, 695; 2000).

But it is still below the target for most national research funding agencies, which aim to fund between $30 \%$ and $40 \%$ of applications. And in some research areas, such as cancer, the FP6 success rate is as low as 15\%.

Researchers are frustrated by the cumbersome application procedure. "Application for European Union (EU) research grants is ridiculously complicated, given the relatively modest amount of money that you can expect at the end of the day," says Karl Tryggvason, a cell biologist at the Karolinska Institute in Stockholm, Sweden, whose application has been recommended for funding.

The complexity has its roots in a new EU philosophy. This focuses funding on "solving problems that are relevant to European communities and industries" and aims to bring industry and the ten accession countries those who will join the EU next year — into the research fold.

Most of the money is allocated through two new schemes - Integrated Projects and Networks of Excellence - which are intended to foster the formation of large consortia.

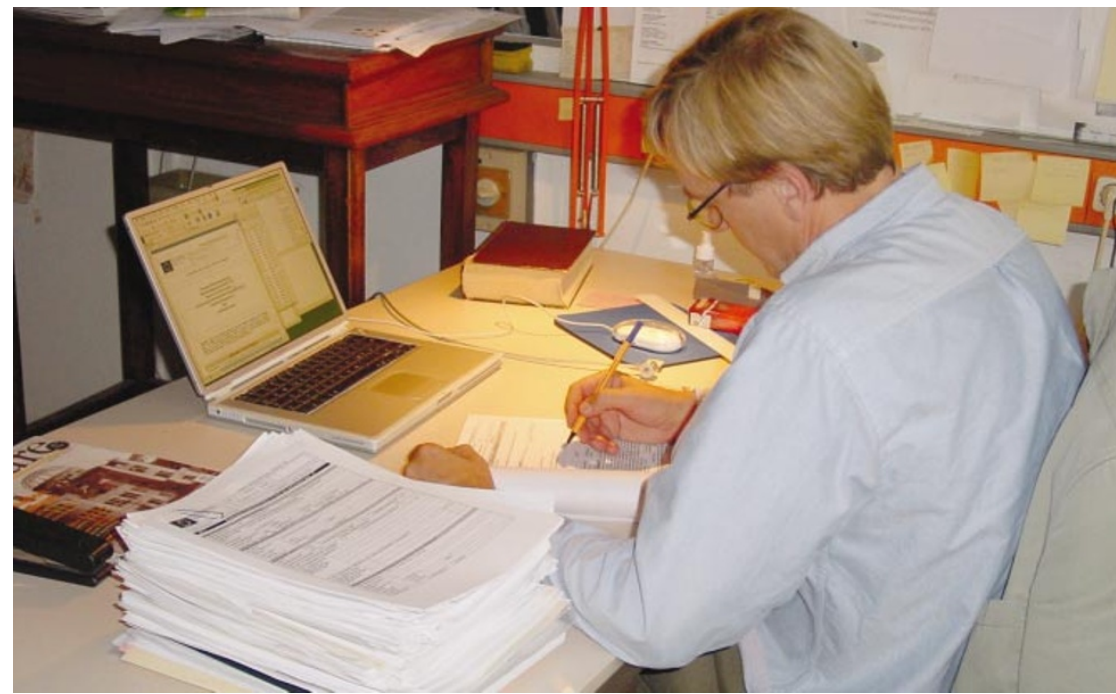

Long nights: the application process for European funding has proved complex and time consuming.

The Networks of Excellence scheme requires an interdisciplinary consortium of scientific groups from at least three countries, one of which is preferably an accession country.

The requirements are so complex that the commission urged researchers to use professional consultancies to help them prepare their applications. It admits that it received fewer applications under this scheme than it was expecting - and that of the thousand or so it did receive, many were rejected for not adhering closely enough to the requirements.

Many applications involved consortia of up to 40 groups, but this failed to impress Achilleas Mitsos, director-general of the research commission. "The objectives of Networks of Excellence were not adequately understood," he says. "The main intention was to promote integration, not sheer size."

The commission is also disappointed at the failure of some of the political aims of FP6, given the low participation of industry and the accession countries. A researcher at Danone, a Paris-based food company, is not surprised: "The Framework Programme is complex - and business needs to move fast."

The EU's aspiration to address political issues through its research programme has long been a bugbear for many scientists, who argue that it is hard to reconcile with selecting the best scientists for funding.

"Scientific excellence was at the very centre of the evaluation," says Mitsos. "But we also had to make sure that European citizens will truly benefit from European research." The commission plans to provide clearer guidelines for future calls.

\section{Companies vie to put all your genes on a chip}

\section{Carina Dennis}

The race is on to produce a commercial DNA microarray that covers the whole human genome.

Applied Biosystems of Foster City, California, announced on 22 July that it plans to have a 'whole-genome chip' on the market by the end of the year. In response, Affymetrix, based at Santa Clara, California, and Agilent Technologies in Palo Alto, California, immediately announced that they intend to do the same.

DNA microarrays allow researchers to assess the level of expression of thousands of genes at a time (see page 610), and a single array for the whole human genome would be an important tool, experts say. Scientists will be queuing up to buy the arrays, says John Hogenesch, a molecular biologist at the Genomics Institute of the Novartis Research Foundation in San Diego.

No one knows how many genes there are in the human genome (see Nature 423, 576; 2003), but the number represented on the arrays under development ranges from 31,000 to 39,000 . "I suspect that the companies are making an informed guess and early versions will be a first step - though a great first step," says Richard Young, a geneticist at the Whitehead Institute for Biomedical Research in Cambridge, Massachusetts.

The three firms are already jockeying for position. Stephen Fodor, chief executive of
Affymetrix, points out that his company has been selling custom versions of a single whole-genome array for the human genome to individual clients for several years. Agilent, meanwhile, says that it already has prototypes for its whole-genome chip.

Researchers have more to look forward to from the chip manufacturers. Both Applied Biosystems and Agilent, for example, have plans to make single whole-genome arrays for mouse and rat available next year.

And Affymetrix has developed prototype arrays for the human 'transcriptome', which represents not only each gene in the genome but also all of the variants of individual genes. 